\title{
The Effect of Professional Identity, Personal Cost and Seriousness of Violation of the Intention to Do Whistleblowing
}

\author{
Armanto Witjaksono $^{1 *}$ and Ratna Laras Wiganitingyas ${ }^{2}$ \\ ${ }^{1,2}$ Accounting Department, Bina Nusantara University, Kemanggisan, Jakarta, Indonesia \\ *corresponding author email: armanto@binus.ac.id
}

\begin{abstract}
The purpose of this study is to empirically examine the influence of professional identity, personal cost, and the seriousness of violations of the intention to whistleblowing. This research is a quantitative study that distribute questionnaires. The population in this study is employees/workers who have worked professionally or are called blue collar workers. The sampling technique uses a random sampling method with criteria for employees who work as accountants. The results of this study concluded that there is a positive influence between professional identity on the intention to do whistleblowing, whereas personal cost and seriousness of the violations do not have a positive influence on the intention to do whistleblowing.
\end{abstract}

Keywords: Professional Identity, Personal Cost, Whistleblowing

\section{INTRODUCTION}

Corruption was the most frequent and most common flow of cheating in Indonesia in 2016 (ACFE 2016 survey). In 2019, based on the results of the survey Corruption Perception Index 2019, Transparency International Indonesia stated that Indonesia has a score of 40 on the CPI and this score is under China. Based on the data above, shows that efforts to eradicate corruption in Indonesia are still very weak. As stated by Mesmer-Magnus [9] that whistleblowing on organizational wrongdoing is becoming increasingly prevalent.

To disclose occupational fraud or the so-called cheating in the necessary work whistleblowing system. Whistleblowing is the most common and effective way to detect fraud (AFCE, 2010) and to uncover (Lee and Fargher, 2013). The effectiveness of the use of Whistleblowing has been recognized by many accountants and regulators in various countries [4]. Survey stated that there were $40 \%$ fraud measures that could be detected using Whistleblowing [11]. Whistleblowing action can be detected quickly and on time. This study analyzes several factors that may reduce the desire of individuals and organizations to report fraud action.

According to Ajzen [2], one's behavior for doing or not doing anything is influenced by intent or intention. This basis suggests that intention can be used as a predictor of someone's willingness to behave. Similarly, the intention of whistleblowing, the motive of a whistler to ventured to give a report and a testimony to the case of fraud he knows can be manifold because a whistleblower can become an important factor in the process underlying good corporate governance. Various studies have been conducted to analyze factors that can affect a person's intention to do whistleblowing. These factors include professional identity, personal cost and the seriousness of violations.

A professional identity is a part of each individual's social identity to ensure that individuals can group themselves based on the profession inherent to them. Professional identity is usually interpreted as the skill of the individual in conducting identification or involvement in a profession [3]. Therefore, everyone who has a profession will tend to have unwavering beliefs in any situation to do whistleblowing because they will have good behavioral control and uphold professional value in the profession that has been working based on existing regulations and implementing a professional code of ethics.

Personal cost is a person's way of the risk of a colleague's retaliation/revenge, which can result in the uninterest of employees to complain wrongdoing. Personal cost represents the subjective norm in Theory of planned behavior, where there is a pressure on social factors that occur as a result of doing or not doing an action [1]. If a person has a lower level of retaliation due to reporting fraud, it 
will increase the intention to do whistleblowing and if the higher the rate of retaliation for reporting fraud, then the lower the intention to do whistleblowing [7].

The seriousness of the offense, the benchmark in the seriousness of cheating has many variations. A company/organization can have a bad impact and is damaged if the level of fraud is happening more seriously than at a less serious level of cheating. It is supported by research of Winardi [9] stating that the seriousness of the offence has an influence on whistleblowing intentions. But not in line with the research of Kaplan and Whitecotton [5] stating that the seriousness of the offence has no effect on whistleblowing intentions.

In Indonesia, Sitorus [12] conclude that collusion was perceived to be the strongest direct influence on commission of fraud with a lesser effect arising from opportunity for fraud and a final direct influence arising from the avoidance of justice. In another term, Witjaksono [14] mentioned that opportunity is the strongest commission of fraud. However, Opportunity does not mediate the relationship between Financial Pressure and Asset Misappropriation Tendency [15].

This research is conducted to test the factors that can affect whistleblowing intention, namely professional identity, personal cost and seriousness of violations. The desire to do this research is due to the results of different research (contradictory) and the gap in the study.

\section{RESEARCH METHOD}

In this study, research objects presented research objectives, namely workers/employees who have worked professionally or called blue collar workers

This quantitative approach is carried out by spreading the questionnaire that the data obtained from the respondent or the population will be used as sample research and sampling done randomly, so that the results of research conclusion can be used in the population where the sample is taken. The study uses the likers scale, which is expressed with SS, S, TS and STS. The questionnaire used will measure three variable independent and one variable independent according to the research model that has been applied.

In sampling, measuring the sample using the formula of Hair et al., (2010:176) where the number of samples as the respondent must correspond with the question indicator used in the questionnaire, by taking into the questions $\mathrm{N}$ x 5 observed variable (indicator) to an x 10 observed variable (indicator). Thus, the results obtained as many as 105 respondents.

Independent variable used is a professional identity, personal cost, and seriousness of infringement. While the dependent variable used is whistleblowing intention. The indicators used in each variable are:

- Professional identity; Use a scale indicator of professional commitments developed by Dwyeret al., (2000)

- Personal Cost; Use an indicator of fear of retaliation (threats), positive and negative consequences for behaviour, and self-availability for commitment

- Seriousness of offence; Use indicators of appraisal level of fraud action measured based on the level of materiality, assessment of the seriousness of the corruption behaviour conducted by the perpetrator in a case if the level of materialization is lowered

- Whistleblowing intention; Using an indicator of a happy response to whistleblowing, a keen interest in whistleblowing, and the desire to be involved as a Whistlerblower

The research uses statistical analysis assisted by SPSS version 23 applications. Statistical analyses conducted include the respondent's descriptive statistical test, the descriptive statistical test variables, data quality tests consisting of validity tests and reliability tests, classical assumption tests consisting of normality test, multicollinearity test, heteroskedasticity test, simultaneous test (F-Test), Coefficient of determination test (test $R^{2}$ ) and partial test (T-Test).

The hypothesis in this study used multiple regression analyses, aiming to see the impact of the intention of performing whistleblowing action using free variables, i.e., professional identity, personal cost and seriousness of violations. The formula used to analyze regression models is as follows: $Y=\alpha+\beta_{1} x_{1}+\beta_{2} x_{2}+\beta_{3} x_{3}+E$

Description: $Y$ (whistleblowing intention), $\alpha$ (constant), $\beta_{1,2,3}$ (independent variable regression coefficient), $x_{1}$ (Professional identity), $x_{2}$ (personal cost), $x_{3}$ (seriousness of offense), $\mathrm{E}$ (Error). This test is performed to indicate whether there are individual or partial independent variables that have an impact on the dependent variables.

\section{RESULT AND DISCUSSION 3.1. Data quality test}

TABLE 1. Results in Professional Identity Validity.

\begin{tabular}{|l|l|l|l|l|l|}
\hline No & Equation & $\begin{array}{l}\text { Questionnaire } \\
\text { validity value }\end{array}$ & R Count & R TABLE & Description \\
\hline 1 & IP1 & 5 & 0.315 & 0.176 & valid \\
\hline
\end{tabular}




\begin{tabular}{|l|l|l|l|l|l|}
\hline 2 & IP2 & 5 & 0.623 & 0.176 & valid \\
\hline 3 & IP3 & 5 & 0.694 & 0.176 & valid \\
\hline 4 & IP4 & 5 & 0.526 & 0.176 & valid \\
\hline 5 & IP5 & 5 & 0.581 & 0.176 & valid \\
\hline
\end{tabular}

TABLE 1 shows that all questions used to measure the variables of a professional identity in this study are considered valid. It is said to be valid if the correlation value is greater than $r$ TABLE.

TABLE 2. Result Test of Validity for Personal Cost.

\begin{tabular}{|c|c|c|c|c|c|}
\hline No & Equation & $\begin{array}{c}\text { Questionnaire } \\
\text { validity value }\end{array}$ & R Count & R TABLE & Description \\
\hline 1 & PC1 & 5 & 0.203 & 0.176 & valid \\
\hline 2 & PC2 & 5 & 0.370 & 0.176 & valid \\
\hline 3 & PC3 & 5 & 0.397 & 0.176 & valid \\
\hline 4 & PC4 & 5 & 0.355 & 0.176 & valid \\
\hline 5 & PC5 & 5 & 0.436 & 0.176 & valid \\
\hline 6 & PC6 & 5 & 0.378 & 0.176 & valid \\
\hline
\end{tabular}

Based on TABLE 2 shows that the correlation value is greater than $r$ TABLE. Therefore, all questions used to measure the personal cost variable in this study are valid.
TABLE 3 below indicates that the question items 1 and 2 are declared invalid, while the question points 3 and 4 are valid. Therefore, it is necessary to impose a revalidate test or an elemental test.

TABLE 3. Result of validity of violations

\begin{tabular}{|c|c|cc|c|c|}
\hline No & Equation & \multicolumn{2}{|c|}{$\begin{array}{c}\text { Questionnaire } \\
\text { validity value }\end{array}$} & Description \\
\hline 1 & KP1 & 5 & 0.03 & 0.176 & invalid \\
\hline 2 & KP2 & 5 & 0.169 & 0.176 & invalid \\
\hline 3 & KP3 & 5 & 0.317 & 0.176 & valid \\
\hline 4 & KP4 & 5 & 0.276 & 0.176 & valid \\
\hline
\end{tabular}

TABLE 4. Results of The Elimination of Violations

\begin{tabular}{|c|ccccc|}
\hline No & Questionnaire & \multicolumn{2}{l|}{ R Count R TABLE } & Description validity value \\
\hline 1 & TKP3 & 5 & 0.324 & 0.176 & valid \\
\hline 2 & TKP4 & 5 & 0.324 & 0.176 & valid \\
\hline
\end{tabular}

Meanwhile TABLE 4 can be seen that all the questions used to measure the variable seriousness of the violation in this study are stated to be valid. 
TABLE 5. Result Test of Validity for Whistleblowing Intention

\begin{tabular}{|c|c|c|c|c|c|}
\hline No & Equation & $\begin{array}{c}\text { Questionnaire } \\
\text { validity value }\end{array}$ & R Count & R TABLE & Description \\
\hline 1 & IW1 & 5 & 0.394 & 0.176 & valid \\
\hline 2 & IW2 & 5 & 0.670 & 0.176 & valid \\
\hline 3 & IW3 & 5 & 0.432 & 0.176 & valid \\
\hline 4 & IW4 & 5 & 0.401 & 0.176 & valid \\
\hline 5 & IW5 & 5 & 0.354 & 0.176 & valid \\
\hline 6 & IW6 & 5 & 0.135 & 0.176 & invalid \\
\hline
\end{tabular}

TABLE 5 shows that the question item 1 to 5 is valid, while the question 6 item is declared invalid. It is necessary to have a re-validity test or an elemental test. TABLE 6 can be seen that all the questions used to measure the variable seriousness of the violation in this study are stated to be valid.

TABLE 6. Result Test of Validity for Whistleblowing Intention

\begin{tabular}{|c|c|c|c|c|c|}
\hline No & Equation & $\begin{array}{c}\text { Questionnaire } \\
\text { validity value }\end{array}$ & R Count & R TABLE & Description \\
\hline 1 & IW1 & 5 & 0.530 & 0.176 & valid \\
\hline 2 & IW2 & 5 & 0.650 & 0.176 & valid \\
\hline 3 & IW3 & 5 & 0.431 & 0.176 & valid \\
\hline 4 & IW4 & 5 & 0.392 & 0.176 & valid \\
\hline 5 & IW5 & 5 & 0.404 & 0.176 & valid \\
\hline
\end{tabular}

TABLE 7. Rehabilitee Test Results

\begin{tabular}{|c|c|c|}
\hline Variable & Cronbach's Alpha & Description \\
\hline Professional identity & 0.771 & reliable \\
\hline Personal Cost & 0.612 & reliable \\
\hline Seriousness of infringement & 0.485 & unreliable \\
\hline The intention of whistleblowing & 0.720 & reliable \\
\hline
\end{tabular}

TABLE 7 shows that the professional identity variables, personal cost, and whistleblowing intentions are considered reliable because of Cronbach Alpha value of more than 0.6. While the seriousness of the violation is not reliable because of Cronbach's alpha in the variable the seriousness of the offence is smaller than 0.6.

\subsection{Classic assumption test}

\subsubsection{Test normality}

Based on the spreading data, it located around the diagonal line and following the direction of the diagonal axle. Furthermore, using test normality Kolmogorov Smirnov, we get the value of the Asymp Sig. (2-tailed) is 0.092 which is greater than sig value so it can be concluded that the regression model has fulfilled the normality assumption.

TABLE 8. Test of Multicollinearity

\begin{tabular}{|c|c|l|l|l|c|}
\hline Variable & Tolerance & 0.1 & Vif & 10 & Description \\
\hline Ip & 0.906 & 0.1 & 1.104 & 10 & There is no multicollinearity \\
\hline Pc & 0.904 & 0.1 & 1.106 & 10 & There is no multicollinearity \\
\hline KP & 0.866 & 0.1 & 1.155 & 10 & There is no multicollinearity \\
\hline
\end{tabular}



the variables of the independent do not experience multicollinearity.

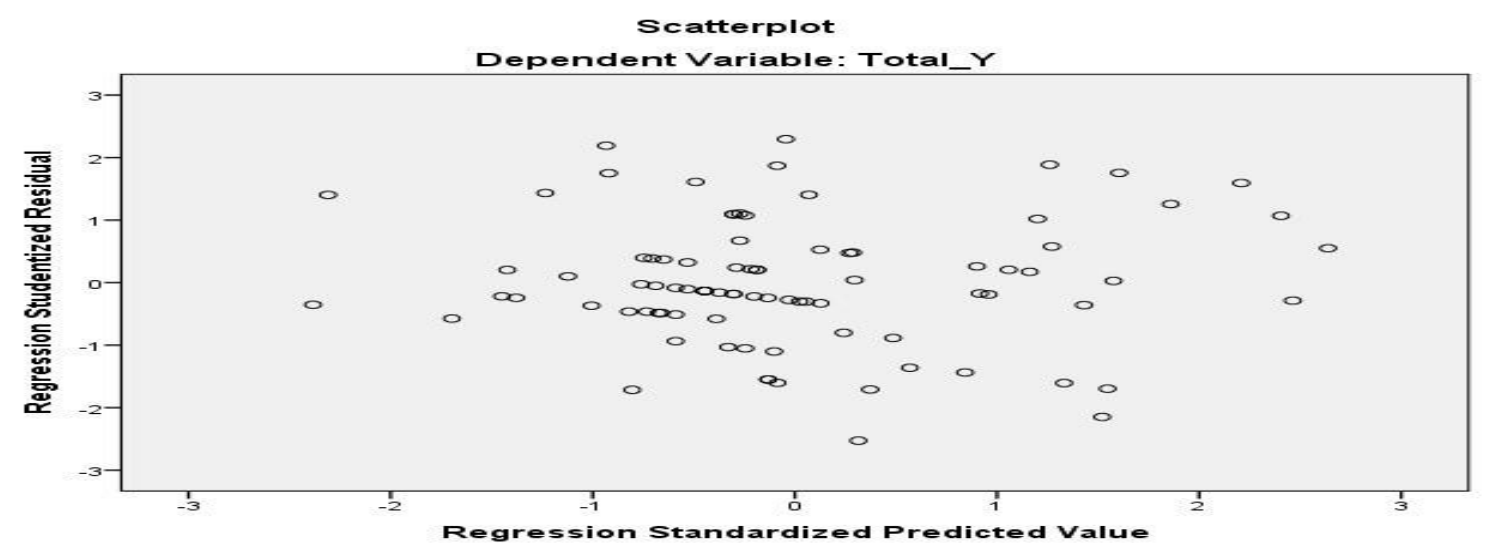

\subsubsection{Heteroskedasticity Test}

According to FIGURE 1 stating that the data points occur above and below or around the number 0 , the dots do not do not accumulate above and below, but rather spread, the spread of the dots is not
FIGURE 1. Heteroskedasticity test results

patterned. So that it can be concluded that the regression model of IP, PC, and KP against IW does not occur heteroskedasticity, so that the results of heteroskedasticity test fulfilled

\subsection{Hypothesis Test}

TABLE 9. ANOVA TABLE

\begin{tabular}{|c|c|c|c|c|c|}
\hline Model & Sum of Squares & Df & Mean Square & $\mathrm{F}$ & Sig. \\
\hline Regression & 56,066 & 3 & 18,689 & 3,330 & $0.023^{B}$ \\
\hline Residual & 471,377 & 84 & 5,612 & 0 & \\
\hline Total & 527,443 & 87 & & & \\
\hline
\end{tabular}

In TABLE 9 states that it can be simultaneously proven that all independent variables affect the dependent variables. So, it is stated that the regression model can be used to detect professional identities, personal cost, and seriousness of the violation jointly affects the intention of whistleblowing.

TABLE 10. Model Summary

\begin{tabular}{|l|l|l|l|l|}
\hline & & & Adjust R & Std. Error of the \\
\hline Model & $\mathrm{R}$ & R Square & Square & Estimate \\
\hline 1 & $.326^{A}$ & .106 & .074 & 2.36889 \\
\hline
\end{tabular}

\subsubsection{Coefficient of Determination}

Test in TABLE 10, a variation of the dependent variable can be described by the independent variable is $10.6 \%$, and the remaining $89.4 \%$ is described by another variable not used in the regression model of this research. Thus, it can be concluded that the professional identity, personal cost, and seriousness of the violations affect $7.4 \%$ of the intention to do whistleblowing, while the remaining $92.6 \%$ is influenced by other variables not examined in this study. 
TABLE 11. ANOVA TABLE

\begin{tabular}{|c|c|c|c|c|c|c|}
\hline & & & & Standardized & & \\
\hline & & Unstanc & Coefficients & Coefficients & & \\
\hline Model & & $\mathrm{B}$ & Std.Error & Beta & Q & Sig. \\
\hline 1 & Constant & 11,530 & 2,494 & & 4,624 & .000 \\
\hline & Total $X_{1}$ & 0.288 & .117 & .268 & 2,470 & .016 \\
\hline & Total $X_{2}$ & 0.115 & 0.104 & .119 & 1,099 & .275 \\
\hline & Total $X_{3}$ & 0.047 & 0.162 & .032 & .287 & .775 \\
\hline
\end{tabular}

\subsubsection{Partial Test (T-Test)}

From the results of TABLE 11, based on the results of a partial t-test, this can be seen Unstandardized coefficient in column $\mathrm{B}$, with a regression model that can be formed in the study is as follows:

$$
Y \quad=\quad 11530
$$

$$
0.288 X_{1}+0115 X_{2}+0047 X_{3}+E
$$

According to TABLE 11, it can be known that the result of regression on the magnitude of value is 11,530 which means that if there is no increase in variable of professional identity, personal cost, seriousness of violations, the value of the variable in's intention to do whistleblowing is 11,530 and coefficient $\mathrm{T}$ of 4,624 .

The result of professional identity variable testing has a calculated $\mathrm{T}$ value of 2,470 > T TABLE of 1,992 . This suggests that the first hypothesis has a positive influence, so the professional identity variables have an influence on the intention of whistleblowing.

The result of the Personal cost variable test has a calculated $\mathrm{T}$ value of $1,099<T$-TABLE of 1,992. This shows that the second hypothesis has no positive influence, so the Personal cost variable has no effect on the intention of whistleblowing.

The result of variable testing the seriousness of the violation has a calculated $\mathrm{T}$ value of $0.287<\mathrm{T}$ TABLE of 1,992. This indicates that the third hypothesis has no influence, so the variable severity of the offense has no influence on the whistleblowing of the intention.

According to Khanifah [6] professional commitment, reward, level of religiosity and moral intensity are some of the variables that have an influence on the intention of doing whistleblowing. Anggraini [1] reveal that the character of Machiavellian and religiosity shows significant effect on whistleblowing intentions.

Although the function of whistleblowing is crucial in exposing wrongdoing due to the nature of corruption that it is not easily detect through formal channels especially in developing countries, due to employees whom witness misconduct in organization prefer not to come forward to disclose the wrongdoing and remain silent due to risky and ambiguity elements associated with the whistleblowing behavior [10].

\section{CONCLUSION}

Based on the results of the test conducted, then we can conclude that professional identity has a positive and significant influence on the intention of whistleblowing, meanwhile Personal cost and the seriousness of the offense have no influence on the intention of whistleblowing.

\section{REFERENCES}

[1] Anggraini, E.S. (2020). Faktor-Faktor Determinant Employee Fraud: Peran Whistleblowing Intention Sebagai Mediator. Thesis in accounting. http://repository.uinjkt.ac.id/dspace/bitstr eam/123456789/51818/1/ERINE\%20SA SKIA\%20ANGGRAINI-FEB.pdf

[2] Ajzen, I. (1991). The Theory of Planned Behavior. Organizational Behavior and Human Decision Processes, 50, 179-211. doi: 10.1016/0749- 5978(91)90020-T.

[3] Aranya et al. (1981).Community Size, Socialization, and the Work Needs of Professionals. Academy of Management Journal.

[4] Dyck,A.,et.al. (2010). Who Blows the Whistle on Corporate Fraud? The Journal of Finance. Volume 65, Issue 6.

[5] Kaplan,S.E., Whitecotton,S.M.(2001), An Examination of Auditors' Reporting Intentions When AnotherAuditor Is Offered Client Employment, Auditing A Journal of Practice \& Theory 20(1):4563, DOI:10.2308/aud.2001.20.1.45.

[6] Khanifah, K., Alfie, A.A., \& Maeni (2019). The Intention of Whistleblowing: The Effect of Professional Commitments, Organizational Commitments, Legal Protection, Reward, Level of Religiousity, and Moral Intensity of Internal Auditor (Case Study at Primary Tax Office in Semarang). Advances in 
Social Science, Education and Humanities Research (ASSEHR), volume 140. 3rd Annual International Seminar and Conference on Global Issues (ISCoGI 2017) https://download.atlantispress.com/article/55916208.pdf

[7] Kuncara,et.al. 2013. Determinants of Internal Whistleblowing Intentions in Public Sector: Evidence from Indonesia. SHS Web of Conferences 34(2):01002.

[8] Lee,G and Fargher,N.L. (2013). Companies Use of Whistle-Blowing to Detect Fraud: An Examination of Corporate WhistleBlowing Policies . Journal of Business Ethics. 10.1007/s10551-012-1348-9.

[9] Mesmer-Magnus, J.R., Viswesvaran, C. Whistleblowing in Organizations: An Examination of Correlates of Whistleblowing Intentions, Actions, and Retaliation. J Bus Ethics 62, 277-297 (2005). https://doi.org/10.1007/s10551005-0849-1.

[10] Mohamed-Isa, A., Latiff, A., Osman, M., \& Ahmad, A.H. (2020). Determinants of Whistleblowing Intention in Organization. Journal of Environmental Treatment Techniques Volume 9, Issue 1, Pages: 54-58 DOI:10.47277/jett/9(1)85

[11] Samuels,JA., Pope, KR. (2014). Are Organizations Hindering Employee Whistleblowing? Attention to Detail Is Essential in Implementing Effective Fraud Reporting Programs. Journal of Accountancy. 218(6),42.

[12] Sitorus, Tumpal Wagner and Scott, Donald Robert, The Roles of Collusion, Organisational Orientation, Justice Avoidance, and Rationalisation on Commission of Fraud: A Model Based Test (November 8, 2008). Review of Business Research, Vol. 8, No. 1, pp. 132147, June 2008, Available at SSRN: https://ssrn.com/abstract $=1297948$

[13] Winardi (2013).The influence of Individual and Situasional Factors on Lower-Level Civil Servants' WhistleBlowing Intention in Indonesia. The Journal of Indonesian Economy and Business. Vol 28, No 3.

[14] Witjaksono, A (2012). Faktor-faktor Terjadinya Fraud dalam Bisnis. Jurnal Gici, Vol.1 No. 2. Pp. 72- 86

[15] Yusrianti, H., Ghozali, I., \& Yuyetta, E.N. (2020). ASSET MISAPPROPRIATION TENDENCY: RATIONALIZATION, FINANCIAL PRESSURE, AND THE ROLE OF OPPORTUNITY (STUDY IN INDONESIAN

GOVERNMENT
SECTOR). Humanities and social sciences, $\quad 8, \quad 373-382$. https://doi.org/10.18510/hssr.2020.8148 